\title{
Ulama dan Jawara: Studi tentang Persepsi Ulama terhadap Jawara di Menes Banten Selatan
}

\author{
Karomani \\ ABSTRACT \\ Ulama (religious leader) and jawara (gank leader) become prominent local elites in Menes, \\ South Banten. Long history of those two leaders resulted in amalgamation of both elites: \\ alongside with pure ulama, there is also a group of ulama who is also jawara. Both elites \\ have positive perception to each other. Jawara-ulama was perceived by ulama as figures who \\ develop, maintain and preserve Banten cultural art. Jawaras are loyal to ulama and protect \\ ulama as well. On the other hand, jawara from outside of ulama group was negatively \\ perceived, assuming bad habits such as disobedience toward religious principles, bandit, \\ doing many violence act. The perception of ulama toward jawara was affected by a closeness \\ in terms of relationship with jawara, a resemblance of beliefs, values, worldview, \\ religious understanding, prejudice and life experience.
}

Kata kunci: ulama, jawara, persepsi negative, prasangka, kebudayaan Banten

\section{Pendahuluan}

Ulama, jawara, dan umaro di Banten telah menjadi suatu konfigurasi kepemimpinan yang satu sama lain saling menunjang. Ulama memiliki pengaruh kuat dalam bidang keagamaan, jawara memiliki pengaruh kuat dalam bidang adat, dan umaro memiliki pengaruh kuat dalam jaringan kekuasaan pemerintahan. Ulama, dengan ilmu agama yang dimilikinya, menjadi rujukan utama masyarakat setempat dalam menyelesaikan berbagai masalah sosial yang berdimensi vertikal dan horisontal. Jawara, dengan kekuatan ekonomi dan fisiknya, menjadikan wilayah Banten aman, karena umumnya pihak-pihak yang berniat merusak ketentraman warga akan berhadapan dengan jawara yang umumnya tergabung dalam perkumpulan persilatan.

Kepemimpinan ulama atau kiai dan jawara, sebagaimana diakui Dewi (2003:243), merupakan simbiosis mutualisme yang tidak terpisahkan dalam konstruk sosial dan budaya masyarakat Banten. Meskipun elite ulama dan jawara satu sama lain keberadaanya saling menunjang, di antara mereka acapkali terjadi hubungan yang kurang harmonis karena perbedaan peran dan kepentingan. Ulama, misalnya, yang lebih mendekatkan diri pada konsep kepemimpinan agama, dan jawara (yang bukan tipe jawara ulama) yang lebih memfokuskan pada kepemimpinan adat karuhun berbeda kepentingannya satu sama lain. Antara jawara dan ulama, dilihat dari aspek ini, ada 
konflik permanen. Jawara, di satu sisi, berkepentingan dengan adat atau tradisi karuhun yang dipengaruhi budaya Hindu, sementara ulama di sisi lain berkepentingan dengan proses islamisasi dan berusaha mengikis pengaruh Hindu tersebut (Sunatra, 1997:125).

Konflik antarelite ulama dan jawara tidak hanya disebabkan oleh perbedaan peran dan kepentingan elite yang bersifat politik atau ekonomi, tetapi bisa juga disebabkan oleh masalah komunikasi antarelite itu seperti kesalahan pemaknaan simbol, persepsi, prasangka, dan lain sebagainya. Selain itu, perbedaan latar belakang budaya, nilai, norma, sikap, dan pandangan hidup di antara mereka dapat memicu konflik atau hubungan yang kurang harmonis antarelite tersebut. Tulisan ini mengkaji dan memahami bagaimana persepsi elite ulama terhadap elite jawara di Banten selatan khusunya di wilayah Menes.

Dalam tulisan ini, daerah Menes dijadikan wilayah kajian penelitian karena daerah tersebut di Provinsi Banten umumnya, dan di Kabupaten Pandeglang khususnya, merupakan daerah basis pendidikan dan tempat lahirnya tokoh-tokoh berpengaruh di tingkat lokal dan di tingkat nasional. Menes, sejak awal abad ke-20, telah menjadi salah satu pusat pendidikan Islam dengan berdirinya lembaga pendidikan Mathlaul Anwar dan daerah ini juga menjadi basis pergerakan menentang kolonialisme yang heroik di Banten, seperti yang terjadi pada tahun 1926 (peristiwa pemberontakan komunis di Banten).

\section{Konsep Persepsi Sosial}

Dalam psikologi umum, dikatakan bahwa persepsi adalah pengamatan secara global, belum disertai kesadaran; sedang subjek dan objeknya belum terbedakan satu dari yang lainnya baru ada proses “memiliki tanggapan” (Kartono, 1996:61). Pendapat ini berbeda dengan apa yang dikatakan Singer (dalam Samovar, 1981:37) yang menjelaskan persepsi adalah proses internal yang memungkinkan kita memilih, mengorganisasikan, dan menafsirkan rangsangan dari lingkungan kita, dan proses tersebut memengaruhi prilaku kita.
Persepsi, sebagaimana dikatakan Wilmot (dalam Purwasito, 2003:175), adalah cara organisme memberi makna. Persepsi merupakan suatu proses menafsirkan pesan atau informasi melalui inderawi. Persepsi adalah inti komunikasi sedangkan penafsiran (interpretasi) adalah inti persepsi yang identik dengan penyandian balik dalam proses komunikasi. Persepsi adalah pengalaman tentang objek, peristiwa, atau hubungan-hubungan yang diperoleh dengan menyimpulkan informasi dan menafsirkan pesan (Rakhmat, 2000:51).

Penjelasan lain dipaparkan Rich (1974:16) bahwa persepsi dapat didefinisikan sebagai proses yang memungkinkan suatu organisme menerima dan menganalisis informasi. Menerima, di sini, adalah menunjuk pada sensasi (indera) atau proses ketika informasi datang kepada kita melalui sensasi (indera) kita. Tentu saja, manusia sebagaimana dikatakan Rich dalam definisinya, tidak hanya sekedar menerima atau mengindera stimuli; tetapi juga menganalisis apa yang ditangkap melalui indera tersebut. Persepsi, secara singkat, dikatakan Cohen adalah "interpretation of sensations as representatives of external objects; perception is apparent knowledge of what is out there" (Cohen dalam Fisher dan Adam,1994:55).

Mulyana (2001:168) menjelaskan bahwa persepsi meliputi penginderaan, atensi, dan interpretasi. Penginderaan (sensasi) terkait dengan alat-alat indera kita baik indera peraba, penglihat, pencium, pengecap, ataupun indera pendengar. Atensi terkait dengan perhatian kita terhadap objek sebelum kita merespon atau menafsirkan kejadian atau rangsangan tersebut. Interpretasi adalah meletakkan suatu rangsangan bersama rangsangan lainnya sehingga menjadi suatu keseluruhan yang bermakna (Goodarce dan Foler dalam Mulyana, 2001: 169). Senada dengan Mulyana, Devito (1997:89) mengatakan proses persepsi meliputi tiga tahap, yakni: (1) stimulasi alat indra terjadi; 2) stimulasi ini ditata; dan 3) stimulasi ini ditafsirkan, dievaluasi.

Persepsi manusia terbagi dua, yakni persepsi terhadap objek (lingkungan fisik) dan persepsi terhadap manusia (persepsi sosial). Persepsi terhadap objek melalui lambang-lambang fisik, 
sedangkan persepsi terhadap orang melalui lambang-lambang verbal atau nonverbal. Persepsi terhadap objek menanggapi sifat-sifat luar, sedangkan persepsi terhadap orang menanggapi sifat-sifat luar dan dalam (perasaan, motif, harapan, dan sebagainya). Objek tidak bereaksi sedangkan manusia bereaksi. Itu sebabnya, persepsi terhadap manusia dapat berubah dari waktu ke waktu, lebih cepat daripada persepsi terhadap objek fisik. Apa yang dimaksud dengan persepsi dalam tulisan ini adalah ditujukan pada jenis persepsi terhadap manusia bukan pada objek fisik. Persepsi dalam konteks ini juga tidak ketat merujuk pada pengertian persepsi dalam psikologi, melainkan lebih pada pengertian pemaknaan atau penafsiran seseorang pada keberadaan orang lain. Dengan perkataan lain, persepsi dalam tulisan ini lebih ditujukan pada tanggapan (penerimaan) langsung dari sesuatu (serapan), bukan ditujukan pada proses psikologis seseorang dalam mengetahui beberapa hal melalui panca indranya (Moeliono, 1996:759; Sarwono, 2002:94).

Persepsi terhadap manusia atau persepsi sosial bisa berbeda beda. Hal ini disebabkan oleh jenis faktor pengalaman, faktor selektivitas, faktor dugaan, faktor evaluatif, dan faktor kontekstual. (Mulyana, 2001:176-196; Fisher dan Adam,1994:5760). Persepsi seseorang bergantung pada pengalaman. Hal ini tampak, misalnya, pada cara orang bekerja, dan menilai pekerjaan mana yang baik dan yang buruk; cara orang makan dan menilai makanan yang lezat dan yang tidak; cara orang mengukur kecantikan seseorang, dan lain sebagainya. Semuanya itu bergantung pada pengalaman sebelumnya yang melatari orang tersebut. Penafsiran manusia, dalam hal ini, karena pengalaman yang berbeda pasti memunculkan penafsiran dan penilaian yang berbeda pula.

Persepsi bergantung pada selektivitas. Setiap saat manusia diberondong oleh jutaan rangsangan indrawi, dan tidak semua rangsangan itu diperhatikan melainkan hanya yang tertentu saja yang menarik atensi kita. Atensi ini merupakan faktor utama yang menentukan selektivitas kita atas berbagai rangsangan itu. Atensi ini dipengaruhi oleh faktor internal seperti faktor biologis (lapar, haus dan sebagainya), faktor fisiologis (sakit, lelah, sehat, dan lain sebagainya), faktor sosial budaya seperti gender, agama, tingkat pendidikan, pekerjaan, status sosial, dan bahkan faktor-faktor psikologis, seperti motivasi, pengharapan, emosi, dan lain sebagainya. Selain oleh faktor internal, atensi dipengaruhi juga oleh faktor eksternal seperti gerakan, intensitas, kekontrasan, kebaruan, dan perulangan objek (Rich, 1974: 19-20).

Persepsi bergantung pada dugaan. Hal ini didasari oleh kenyatan bahwa data yang diperoleh mengenai objek melalui pengindraan tidak pernah lengkap, sehingga persepsi itu merupakan loncatan langsung pada kesimpulan. Sebagai contoh, tampak misalnya, ketika melihat gunung es, maka hanya melihat bagian atasnya saja, namun terbiasa menduga ada juga bagian gunung es itu di bawah permukaan air.

Persepsi bersifat evaluatif, artinya tidak ada persepsi yang bersifat objektif. Manusia melakukan interpretasi berdasarkan pengalaman masa lalu dan kepentingannya. Persepsi adalah suatu proses kognitif psikologis dalam diri yang mencerminkan sikap, kepercayaan, nilai, dan pengharapan yang kita gunakan untuk memaknai objek.

Persepsi bersifat kontekstual,suatu rangsangan dari luar harus diorganisasikan. Dari semua pengaruh yang ada dalam persepsi kita, konteks merupakan salah satu pengaruh yang kuat. Angka tiga belas (13), misalnya, dalam konteks tertentu bisa dibaca atau dipersepsi atau dimaknai orang dengan huruf $\mathrm{B}$.

Di samping disebabkan jenis faktor pengalaman, selektivitas, dugaan, evaluatif, dan kontekstual, Samovar dan Porter (1981:38) sebagaimana juga dijelaskan Mulyana (2001:197) mengemukakan beberapa unsur budaya yang memengaruhi persepsi, yaitu: kepercayaan, nilai, dan sikap; pandangan dunia; organisasi sosial; tabiat manusia; orientasi kegiatan; persepsi tentang diri dan orang lain. Kepercayaan terkait dengan anggapan subjektif bahwa sesuatu objek atau peristiwa mempunya ciri atau nilai tertentu. Nilai adalah komponen evaluatip dari kepercayaan. Sikap adalah reaksi perasaan terhadap sesuatu. Pandangan dunia adalah orientasi budaya 
terhadap Tuhan, kehidupan, dan isu-isu filosofis lainnya. Organisasi sosial adalah perkumpulan massa. Tabiat manusia adalah pandangan kita tentang siapa kita, bagaimana sifat dan watak kita. Orientasi kegiatan adalah terkait dengan apakah manusia atau individu itu mementingkan proses atau hasil dari suatu kegiatannya. Sedangkan persepsi tentang diri dan orang lain terkait dengan apakah manusia atau individu itu bersifat individualis atau kolektivis. Selain dipengaruhi unsur budaya di atas, persepsi kadang dipengaruhi oleh prasangka (Rich, 1974:38).

\section{Persepsi Ulama terhadap Perilaku Jawara}

Ulama atau kiai di Banten Selatan, seperti di daerah Menes saat ini, bisa dikategorikan ke dalam dua tipikal ulama. Pertama, ulama senior atau ulama sepuh (syaehuna). Ulama ini, dari segi usia, sudah berada di atas 75 tahun, dan dari segi keilmuan atau keulamaan lebih berkharisma di mata masyarakat dibandingkan ulama lain. Ulama ini biasanya memiliki pesantren atau sekolah agama mulai dari tingkat dasar sampai perguruan tinggi. Ulama tipe ini, di daerah Menes, salah satunya yang masih hidup sekarang adalah K.H. Ma'ani Rusdi, pemimpin pondok dan sekolah Malnu (Mathaul Anwar Linahdatul Ulama). Malnu adalah lembaga pendidikan yang didirikan K.H Yasin, K.H. Junaedi, dan K.H Ma'ani Rusdi pada tahun 1968 sebagai pecahan dari Matlaul Anwar (MA) yang lebih dulu berdiri pada tahun 1916 oleh K.H M Yasin, K.H Mas Abdurrahman, dan K.H Mohammad Sholeh. Malnu, secara harfiah, pengertiannya adalah munculnya cahaya mengikuti bangkitnya ulama. Latar belakang munculnya lembaga ini adalah adanya ketidaksepakatan K.H Yasin dan putranya K.H M Junaedi, dan juga K.H Ma'ani Rusdi terhadap lembaga pendidikan yang bernama MA (secara harfiah berarti munculnya cahaya) yang dinilai berpaham Muhammadiyah (aliran pembaharuan). Bahkan kerap MA dituding para alumninya sendiri sebagai perpanjangan ajaran wahabi. Gerakan wahabi adalah gerakan pembaharuan Islam di Arab Saudi yang dipelopori
Muhammad ibn Abdul Wahab (meninggal 1792)). Gerakan ini sering dianggap terlalu revolusioner oleh karena gagasan-gagasan yang dikemukakannya, dilihat menurut ukuran zamannya terlalu radikal. Gerakan wahabiah menyerang sufisme tanpa ampun. Berkat gerakan inilah bid'ah, khurafat, dan takhayul yang merajalela dalam dunia Islam terkikis habis (Amien Rais dalam John J Donohue dan John L Espositi, 1989:x).

Mathlaul Anwar, meskipun merupakan lembaga pendidikan agama tertua di Menes, akhirnya mengalami perpecahan karena lembaga ini acapkali diidentikkan dengan gerakan pembaharuan. Beragam lembaga pendidikan di Menes kemudian bermunculan sebagai pecahan dari MA, seperti Nurul Amal (cahaya amal) yang didirikan oleh K.H. Jirjis (almarhum) di Kadubangkong Menes, dan Anwarul Hidayah (cahaya hidayah) yang didirikan K.H Abdulatif (almarhum) di Nanggorak Menes. K.H. Ma'ani Rusdi di Menes saat ini merupakan satu-satunya ulama sepuh. Ia memiliki pengalaman bermasyarakat dan bernegara pada berbagai zaman, dari zaman penjajahan, zaman kemerdekaan, hingga zaman pascakemerdekaan (dari Orde Lama, Orde Baru sampai Orde Reformasi saat ini).

Selain ulama sepuh, tipe ulama yang kedua di Menes adalah ulama yang lebih muda, yang berumur sekitar 55 atau 60 tahunan. Ulama ini bisa digolongkan ke dalam dua tipe ulama, yaitu ulama yang relatif terpelajar (selain lulusan pondok juga berpendidikan tinggi) dan ulama yang hanya lulusan pesantren. Ulama lulusan pondok umumnya memiliki pesantren, sementara ulama lulusan perguruan tinggi tak semuanya memiliki pesantren.

Dilihat dari karakter kejawaraan, ulama di Menes bisa diklasifikasikan ke dalam dua klasifikasi ulama, yaitu ulama jawara, dan ulama biasa (bukan ulama jawara). K.H. Haerudin termasuk ulama jawara, sementara K.H. Ma'ani, K.H. Hakim, dan K.H. Suhri Utsman, termasuk ulama nonjawara, meskipun K.H. Suhri Utsman itu sendiri mengenal beberapa jawara, beliau tidak disebut kiai jawara karena tidak memiliki ilmu hikmah yang kuat. Kiai jawara yaitu kiai yang selain menganut ilmu hikmah 
(ilmu kebatinan) yang kuat yang dianggap memiliki kesaktian juga banyak bergaul dengan jaringan para jawara. Sementara ulama biasa, yaitu ulama yang meskipun memiliki ilmu hikmah, tetapi tidak dikenal memiliki kekuatan atau kesaktian dan tidak banyak bergaul dengan para jawara melainkan hanya mengajar ngaji atau menghadiri pengajianpengajian di pesantren. Ilmu hikmah pada umumnya adalah ilmu yang dimiliki para kiai baik kiai jawara maupun bukan kiai jawara. Hal ini ditegaskan oleh Hufad berikut ini:

Umumnya kiai identik dengan kepemilikan ilmuilmu agama yang tinggi, ahli hikmah dan kebatinan, memiliki dan mengasuh pesantren serta memimpin masyarakat. Kiai dipandang sebagai orang yang memahami nilai pesan ajaran-ajaran agama, dan menjadi sosok yang paling dekat dengan pusat kekuatan supranatural. Ia memiliki kekuatan magis atau ilmu hikmah dan menguasai kitab-kitab kuning, serta diangap dapat melakukan perbuatan yang tidak dapat dikerjakan oleh orang-orang biasa (Hufad, 2004: 227).

Ilmu hikmah yaitu ilmu yang berkaitan dengan bacaan-bacaan dari ayat-ayat AlQuran yang kadang disertai puasa dan wiridan seperti bacaan hamdallah, istigfar, dan sholawat pada nabi Muhammad SAW. Ilmu hikmah ini oleh sebagian orang dipandang berguna untuk kedigjayaankedigjayaan, seperti kebal (tahan) bacok, dan lain sebagainya. Kiai jawara selain memiliki jaringan pergaulan dengan komunitas para jawara, dulu kiai ini dipersepsikan para kiai sebagai orang yang suka berjudi dan bergaul dengan para jawara. Meskipun demikian, judi dan bergaul dengan jawara dilakukan mereka dengan alasan untuk tetap berdakwah.

Dalam pandangan ulama, baik ulama jawara maupun ulama biasa, jawara itu pada awalnya memang lahir dari kiai. Ulama umumnya berpersepsi bahwa ketika tekanan pemerintah kolonial Belanda terhadap masyarakat pribumi demikian kuat, hal ini menyebabkan munculnya perlawananperlawanan rakyat dan pusat perlawanan berada pada kiai. Para kiai ini umumnya memiliki dua kelompok santri. Pertama, adalah santri yang mempunyai bakat di bidang ilmu agama, dan kedua adalah para santri yang mempunyai bakat yang berkaitan dengan bela diri. Sosok santri yang kedua inilah yang oleh kiai dibina dalam hal kekuatan fisik, dan kemudian menjadi jawara yang biasa diklasifikasikan sebagai ulama jawara.

Persepsi para kiai di atas, sejalan dengan yang dikatakan Adimihardja (1991 dalam Hufad, 2004:211), pada awalnya para jawara itu terkait dengan latar historis pada era kekuasaan sebelum ada pengaruh kekuasaan kesultanan Banten. Jawara muncul tatkala adanya basis pelatihan (kesatrian) para pasukan pengawal kerajaan Padjadjaran yang berada di bawah kekuasaan Pucuk Umun di Banten Lama. Para jawara merupakan perantara atau penghubung antara penguasa Padjadjaran dengan rakyatnya, yang bertugas mengawasi kelompok-kelompok masyarakat, memungut upeti, serta mengatur tugas lain untuk kepentingan kerajaan, yang dilakukan kadang-kadang dengan kekerasan demi berjalannya roda pemerintahan tradisional. Setelah raja Padjadjaran dan Pucuk Umun menyerah pada Sultan Hasanudin, para jawara yang setia pada kerajaan itu menyerah dan beralih menjadi pengikut Sultan Hasanudin. Dalam perjalanannya kemudian, mereka bukan saja mahir dalam ilmu bela diri dan kekebalan, tetapi mereka memelajari agama Islam dari para kiai; aktualisasi kejawaraannya dilandasi oleh nilai-nilai dan norma agama sehingga disebut pula sebagai jawara ulama.

Dalam persepsi para ulama, jawara saat ini di Menes berkembang menjadi dua tipikal jawara, yaitu jawara yang dekat dengan kiai dan jawara yang tidak dekat dengan kiai. Jawara yang dekat dengan kiai adalah jawara yang sedikit banyak berpendidikan agama dan sering berkomunikasi dengan kiai, sementara jawara yang jauh dengan para kiai adalah jawara yang umumnya tidak berlatar pendidikan agama dan tidak membangun komunikasi dengan para kiai. Jawara ini oleh para ulama sering disebut baragajul (tidak memiliki pekerjaan tetap dan sering berbuat onar). Tipikal jawara seperti ini identik dengan apa yang dikatakan Sunatra (1977:183;) dan Lubis (2004:127) sebagai jawara yang semata mata menggunakan elmu hideung (ilmu hitam) yang tidak berdasarkan ajaran agama Islam, melainkan masih berbau ajaran animisme. Termasuk elmu hideung yang dimiliki 
jawara di luar ulama itu ialah jangjawokan. Jangjawokan, dalam Ensiklopedia Sastra Sunda (1997:80), adalah sejenis puisi (mantra) Sunda. Ia digunakan pada waktu akan melakukan suatu pekerjaan agar berhasil baik dan yang melakukannya selamat. Diucapkan, misalnya, pada waktu akan berjalan, duduk, berdiri, berdandan, bertandang, berkumpul, menyauk beras, mencuci beras, makan, minum, makan sirih, dan lain-lain.

Selain menggunakan jangjawokan, beberapa benda tertentu diyakini oleh jawara yang berada di luar komunitas kiai sebagai benda yang memiliki kekuatan magis. Jantung pohon pisang tertentu (panggalek), misalnya, diyakini bisa dipakai untuk bermain judi agar selalu menang judi. Demikian juga buntut (buritan ) kadal atau sejenis komodo kecil yang bercabang dua yang lepas dengan sendirinya tepat pukul 12 siang pada hari Jumat, misalnya, diyakini mereka berguna untuk elmu (ilmu) nyandung (beristri lebih dari satu) agar para istri itu damai dan tentram tidak saling cemburu.

Tipikal jawara yang di luar komunitas para kiai di atas, lebih jauh secara historis dikemukakan Kartodirdjo (1984:56-164) bahwa pada saat kesultanan Banten dihapuskan Daendeles pada abad ke-19, keadaan di Banten menjadi kacau dan seluruh tatanan sosial hampir ambruk. Dalam situasi seperti ini, munculah para pemimpin dari kalangan kiai dan elite pedesaan lainnya. Mereka secara radikal membangkitkan semangat perlawanan terhadap penguasa asing dan juga terhadap pamong praja. Dalam situasi seperti ini, perampokan, penyamunan, pembegalan terjadi di mana-mana. Malahan dalam perkembangannya kemudian, sekitar tahun 1880-an, muncul perampok dan bandit tulen yang tidak ada kaitannya dengan perlawanan. Mereka merampok dan melakukan penggarongan tanpa pilih bulu. Mereka inilah yang membuat onar dan menjadikan nama jawara menjadi cemar. Hal ini lalu dimanfaatkan oleh pemerintah kolonial untuk meruntuhkan citra para pejuang yang sesungguhnya, dengan cara mencap atau memberi label bahwa semua kaum jawara Banten adalah bandit, sehingga perlawanan dalam bentuk gerakan sosial yang bermaksud melawan penjajah seperti perlawanan Ki Wasid di Cilegon (1888), dianggap onlusten (keonaran), ongeregeldheden (pemberontakan), complot (komplotan), woelingen (kekacauan), dan onrust (ketidakamanan). Jadi, sejak dahulu tidak dipungkiri memang ada jawara yang murni bandit di luar kendali kiai tersebut. Hal ini dikemukakan Kartodirdjo berikut ini:

Pada tahun 1886 dalam masyarakat yang penuh keresahan timbul kekeruhan yang disebabkan oleh merajalelanya gerombolan perampok di bawah pimpinan Sakam. Karena sukar ditangkap, pada rakyat ada kepercayaan bahwan ia berjimat dan memiliki kekebalan. Kabar bahwa dia akhirnya ditangkap di Batavia dan meringkuk di penjara sangat menggemparkan. Namun kemudian terbukti bahwa yang ditangkap itu seorang Jaro bernama Suhari. Akhirnya hakim memutuskan bahwa Suhari bukan Sakam, lalu dibebaskan. Sakam yang sesungguhnya beberapa bulan kemudian mati terbunuh dalam suatu konfrontasi dengan alat-alat Negara (Kartodirdjo,1988:56).

Berbeda dengan sosok jawara yang diluar kendali kiai yang peran dan prilakunya dipersepsikan para kiai sebagai sosok yang negatif, jawara yang dekat dengan kiai adalah jawara dalam pengertian yang positif. Jawara ini dipersepsikan oleh ulama berperan sebagai sosok pemelihara, pengembang seni budaya Banten, dan sekaligus sebagai khadam para kiai. Yang dimaksud pemelihara seni budaya tradisi di atas termasuk misalnya seni bela diri (pencak silat) debus, dan seni budaya lain. Sebagai khadam kiai, jawara dipersepsikan ulama sebagai penjaga harta kekayaan pribadi ulama, dan sarana dakwah bagi ulama.

Seni budaya Banten, seperti pencak silat dan debus, yang dibina dan dikembangkan jawara dalam komunitas ulama mendapat apresiasi yang baik di mata ulama, karena kedua seni budaya ini lekat dengan unsur-unsur Islam. Pencak silat aliran Cimande, misalnya, amat kental dengan nuansa agama keislaman, karena ia lahir dari sosok kiai di Bogor. Demikian juga debus di Banten telah berkembang secara turun-temurun yang dalam perjalannya tidak terlepas dari pengaruh agama Islam. Karena lekat dengan unsur budaya Islam 
inilah, maka umumnya ulama berpersepsi positif terhadap seni budaya itu.

Dalam masa kesultanan Banten, diakui memang pengaruh Islam demikian kuat dalam berbagai aspek kehidupan masyarakat Banten. Itu sebabnya, masuk akal manakala pengaruh Islam terhadap kesenian di Banten termasuk kesenian debus demikian kuat nuansa keislamannya karena kesultanan Banten, sebagaimana dikatakan Gulliot et al. (1990:17), yang berdiri sejak abad ke-16 (1527) menjadi dinasti Islam terkokoh di Nusantara. Agama Islam ikut menyuburkan kesenian di Banten karena Islam pada dasarnya tidak melarang berkesenian. Para ulama dalam menyebarkan agama bahkan menggunakan kesenian sebagai salah satu teknik dalam metode dakwahnya. Sebagai buktinya, apabila kita berkunjung pada musium kesultanan Banten, di sana akan ditemui peninggalan-peninggalan ulama seperti gamelan, gendang, kenong, dan goong. Para ulama, konon, bahkan menggunakan pertunjukan wayang yang pada awalnya lekat dengan budaya Hindu sebagai penarik dakwahnya. Jimat Kalima Sada (dua kalimat syahadat) yang muncul dalam cerita pewayangan merupakan kreasi ulama yang berusaha menyesuaikan seni budaya Hindu itu dengan nafas Islam. Debus sebagai salah satu bentuk kesenian rakyat tidak terlepas dari nafas Islam dan tujuan dakwah itu. Karenanya, wajar manakala kesenian yang dibina dan dikembangkan sebagian jawara itu mendapat persepsi positif dari para ulama.

Terkait dengan penampilan sososk jawara secara fisik, seperti sepintas diungkapkan umumnya para ulama berpersepsi sama bahwa jawara di Banten Selatan saat ini berpenampilan biasa-biasa. Persepsi mereka berbeda dengan apa yang dikemukakan dalam Ensiklopdeia Sunda (2000:203) yang menjelaskan ciri-ciri fisik jawara itu seperti berikut ini:

"Jawara disebut juga oah, jagoan. Kata jawara terutama digunakan di daerah Banten. Umumnya laki-laki yang penampilannya sangar. Berpakian celana pangsi, baju kampret, ikat kepala barangbang semplak, kumis panjang melintang, mata merah, tangan penuh dengan akar bahar, membawa golok dengan ikat pinggang kulit tebal dan lain-lain.
Ciri tampilan fisik jawara yang dikemukakan Ensiklopedia Sunda di atas, dalam persepsi para ulama hal itu sebenarnya bagian dari ciri fisik atau tampilan sosok jawara masa lalu. Jawara saat ini meskipun tipikal jawara yang di luar kendali kiai menurut persepsi ulama sudah berbeda sosok tampilan fisiknya dengan jawara dahulu. Pakaian jawara saat ini, dalam kesehariannya, sama saja dengan pakaian masyarakat biasa memakai celana panjang, memakai baju atau kaos, tidak memakai topi laken, tidak memakai celana pangsi, tidak memakai sarung yang dilintangkan seperti jawara dahulu, dan kesannya tidak terlalu sangar atau menakutkan, meskipun kadang tetap di antara mereka suka membawa golok. Meskipun demikian, dalam acara khusus, seperti dalam padepokan persilatan atau acara resmi dalam keorganisasaian kejawaraan, pakaian mereka diakui berbeda dengan warga masyarakat lain. Para jawara dalam acara seperti itu memakai celana pangsi dan "baju dinas" hitam layaknya seorang jagoan. Warna hitam yang dikenakan jawara, bagi para jawara, sebagai cermin keteguhan sikap, dan sekaligus sebagai tradisi kejawaraan

Jawara di Banten Selatan, dalam persepsi para ulama, tidak seperti di tempat lain, memakai tato, memakai bahar, dan asesoris lain yang menyeramkan. Mereka dipersepsikan para ulama mengetahui agama, dan tetap hormat pada kiai. Bahkan, jawara yang buruk kelakuannya pun seandainya mendengar kiai mau dibunuh, mereka akan membela kiai. Faktor inilah yang menyebabkan Banten secara keseluruhan aman dari kasus yang mengancam eksistensi para kiai

Meskipun secara real jawara dalam masyarakat berperan penting, para kiai umumnya berpersepsi sama yakni kiailah (bukan jawara) yang sesungguhnya berperan penting yang memiliki pengaruh kuat dalam kehidupan masyarakat sehari-hari.

Sebagaimana telah dikemukakan, meskipun ulama umumnya berpersepsi bahwa pengaruh mereka dalam masyarakat, khususnya masyarakat Banten Selatan, demikian kuat dibandingkan elite jawara, dan umaro, mereka berpersepsi tidak ada konflik di antara tiga elite itu. Untuk lebih jelas, 


\section{Gambar 1. Persepsi Ulama terhadap Peran dan Perilaku Jawara}

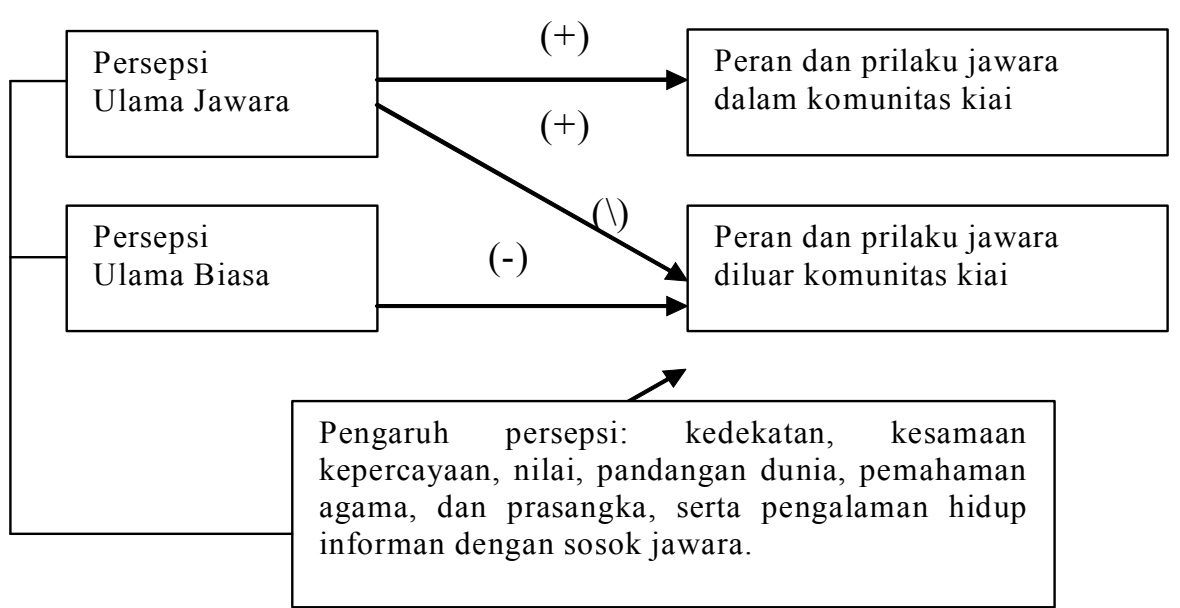

Ket: (+) positif (-) negative (1) tidak selalu positif dan negatif

Gambar 1, melukiskan persepsi ulama terhadap jawara.

\section{Kesimpulan}

Ulama dan jawara di Banten Selatan merupakan elite lokal yang berpengaruh di dalam masyarakat setempat. Ulama di Banten Selatan teridiri dua tipikal ulama, yakni ulama jawara dan ulama biasa. Ulama jawara adalah ulama yang memiliki ilmu kebatinan yang kuat dan memiliki jaringan komunikasi dengan para jawara. Ulama biasa adalah ulama, yang meskipun memiliki ilmu kebatinan atau ilmu hikmah, tidak memiliki jaringan komunikasi dengan para jawara.

Persepsi ulama, baik ulama jawara maupun ulama nonjawara, terhadap perilaku jawara dalam komunitas ulama positif. Jawara dipersepsikan para ulama berperan sebagai sosok pemelihara, pengembang seni budaya Banten, taat beragama, dan sekaligus sebagai khadam para kiai. Persepsi ulama jawara terhadap jawara di luar komunitas ulama negatif. Jawara dipersepsikan mereka sebagai bandit, tidak taat beragama, dan suka berbuat kekerasan. Sementara, bagi ulama jawara, persepsi terhadap perilaku jawara di luar komunitas ulama tidak selalu negatif. Jawara dalam persepsi mereka berperan dalam meredam konflik dan melacak kejahatan di masyarakat.

Persepsi para ulama terhadap jawara dipengaruhi oleh kedekatan, kesamaan kepercayaan, nilai, pandangan dunia, pemahaman agama, dan prasangka, serta pengalaman hidup para ulama dengan sosok jawara.

\section{Daftar Pustaka}

Dewi, Kurniawati H. 2003. “Kepemimpinan Kiai dan Jawara di Banten Pengaruhnya terhadap Good Governance.” Banten: LSPB.

Devito, Joseph A. 1997. Komunikasi AntarManusia. Jakarta: Profesional Books.

Fisher, B Aubrey, dan Katherine LAdam. 1994. Interpersonal Communications Pragmatics of Human Relationships. New York: McGrawHill, Inc. 
Hufad, M. 2004. "Sosialisasi Identitas Kekerabatan pada Keluarga Inti di Menes Banten.” Bandung: Disertasi, PPs Unpad.

Kartono, Kartini. 1996. Psikologi Umum. Bandung: CV Mandar Maju.

Kartodirdjo, Sartono.1984. Pemberontakan Petani Banten 1888. Jakarta: Pustidaka Jaya.

Mulyana, Deddy. 2001. Metodologi Penelitian Kualitatif. Bandung: PT Remaja Rosda Karya.

Moelyono, Anton 1996. Kamus Besar Bahasa Indonesia: Jakarta: Balai Pustidaka.

Purwasito, 2003. Komunikasi Multikultural. Surakarta: Universitas Muhamadiyah.
Rakhmat, Jalaludin, 2000. Psikologi Komunikasi. Bandung: PT Remaja Rosda Karya.

Rich, Andrea L. 1974. Interracial Communication. New York: Harper and Row Publishers.

Sarwono, 2002. Psikologi Sosial Individu dan Teori-teori Psikologi Sosial. Jakarta: Balai Pustidaka.

Samovar, Larry, A, dan Richard, E Porter. 1981. Understanding Intercultural Communication. California: Wadsworth Publishing Company.

Sunantra. 1997. "Integrasi dan Konflik Kedudukan Politik Jawara dan Ulama dalam Budaya Lokal. Studi Kasus Kepemimpinan di Banten.” Bandung: PPs Unpad. 
